\title{
Goat Farming Development Strategy in Benjor Village, Malang Regency, Indonesia
}

\author{
S. Azizah; U. Wisaptiningsih; A.E. Kusumastuti; J.A. Putritamara \\ Socio-economics Department, Animal Science Faculty, University of Brawijaya \\ siti.azizah@ub.ac.id
}

\begin{abstract}
The research aims were to determine strategies in farmers' social capital strengthening to increase trust between farmers and stakeholders, in market structure, and technical-social farmers' empowerment. The study was conducted in Benjor Village, Tumpang District, Malang Regency, and the number of respondents was 30 people. Data analysis methods used in research are SWOT analysis with IFAS (Internal Strategic Factors Analysis Summary) and EFAS (External Strategic Factors Analysis Summary) and continued with AHP (Analytic Hierarchy Process) analysis. The results of the study that the cartesian diagram position of local goat development in Benjor Village in quadrant IV, which means there are more weak points than strength points, more threat points than the opportunity points. Therefore, developing the local goat business needs to change the strategy through strengthening social capital in the trust of both other farmers with stakeholders.
\end{abstract}

Keywords. local goats, social capital, strategy

\section{Background}

Smallholder farmers in Indonesia as subsistence farmers are not categorized as an empowered group, so they need much support from stakeholders to support their business scale. The majority of farmers in Indonesia who are still at a small scale level even do not have bargaining positions. Smallholders in Indonesia generally have the following characteristics: 1) poor farmers who have difficulty meeting their needs are marginalized, 2) their farming businesses are traditionally inherited and subsistence, 3) lack of insight because of the level of education low, so it is difficult to adopt innovations, 4) lack of courage to take farming risks because they are not familiar with new things and are at risk to their financial condition (Kay, 2004)

Local goat is a livestock commodity that has great potential to be developed in several areas that support cultivation, such as Tumpang sub-district, Malang regency. Consumer demand for goat meat is less than chicken meat or beef because Indonesian people's tret it as substitute products. Also, given the price of goat meat, which tends to be expensive and limited availability. However, goat meat can contribute significantly to the fulfilment of Indonesian people's nutrition because it has high protein. Goat fat content 50-65 percent lower than beef, and cholesterol is only 5-39 mg per 100 grams. For people who are running a fat diet, goat meat is better than beef. 
Goat (Capra hircus) is one of the first types of livestock cultivated by humans for the needs of sources of meat, milk, skin, and fur (Chen et al., 2005). Goat farmers in Indonesia are, on average, controlled by traditional farmers, who are running their family business and make a goat farming as a family saving. Even some periods the market demand is high (namely one celebration day like Qurban and aqiqah/baby born tradition) farmers are still in a state cannot make a balanced bargaining position toward broker.

Goat cultivation provides a good prospect for the community because the goat farming can be done in all regions in Indonesia. This farming is promising since the public awareness of the high nutritional value of food is rising. Thus, the amount of goats meat demand will continue to increase and to be one of the export commodities. This was supported by an increased number of goat populations from 2010 to 2018 which was 18.72 million head per year (Livestock and Animal Health Statistics, 2018)

However, the problem currently faced is the consumption of goats that are not as much as beef and chicken. Consumers' assumptions about cholesterol content make them reluctant to substitute beef with goat meat. Besides, the infrastructure and market structure for goat commodities minimize the market share and the condition is worse since goat meat does not have a certificate of domestic food production.

Malang Regency is one of the areas where previously people became beef cattle farmers and then turned into goat farmers because of limited capital. Goat, or often also known as a small ruminant, is herbivorous livestock, which is very popular among Indonesian farmers. This livestock is more easily maintained, can be utilized as waste and by-products of agriculture and industry, easy to breed, and the market is always available at any time and requires relatively little capital compared to large ruminants (Setiadi, 1987).

Goat farming scale for every family is 4-6 goats with abundant feed availability, and this area needs to be developed by the Malang district government in implementing the One Village One Product system. Hopefully, Malang Regency can become a food barn for local goat commodities. Business development needs some support from stakeholders to increase goat business productivity. Therefore research on local goat development strategies is required in Malang through optimizing the production of agribusiness systems, institutions, infrastructure, market structures investment development, and goat logistics system.

\section{Literature Review}

Optimization is the achievement of the best condition, namely as a solution to the problem directed to the maximum and minimum limits. Optimization can be achieved in two ways, namely maximization, and minimization. Maximization is the optimization of production by using or allocating specific inputs to get the maximum profit. Whereas minimization is the optimization of production to produce a certain level of output using the most minimal inputs or costs (Esther, 2013).

Technically, there are 8 (eight) institutions that are important in the development of agribusiness, including: (1) institutions providing farm inputs, (2) capital supply institutions, (3) labor fulfilment institutions, (4) land and irrigation water supply institutions, (5) farming institutions, (6) agricultural processing institutions, (7) agrarian products marketing institutions, and (8) information supply institutions (technology, markets, etc.). Each institution can be run in two ways, individually (soft structure) or collectively (hard structure) (Mardikanto, 2010).

Institutions and policies have always been essential issues in forest management, agriculture, or development in general. History shows that in developed countries, good institutions are the key to successful management of the country, development, markets, trade, or business. So far, the government tends to put more emphasis on economic growth by 
prioritizing the development of physical, technological, economic, and political infrastructure. Very little attention has been paid to building institutional infrastructure (institutions). On the other hand, government policies tend to be inconsistent, always changing and difficult to implement in their entirety. This condition requires serious attention because almost all development failures stem from two fundamental issues, namely policy failure and institutional failure. (Djogo, Sunaryo, Suharjito, Sirait, 2003).

The variety of institutions needed to increase production and income or profits from farming (Mardikanto, 1993). According to Banomyong (2007), there are four key factors to realize a logistics system that can recognize the competitiveness of an industry, including the agricultural sector, namely (1) infrastructure; (2) institutional framework; (3) services; and (4) logistical actors (see picture). These four key factors interact with each other and cannot be separated so that they can realize cost efficiency, availability, security, and responsiveness as forming competitiveness.

According to Portes (1998), social capital is the ability of actors to guarantee benefits by relying on membership in social networks and other social structures. Haridison (2013) concluded that the views of some experts on the conception of social capital are: (1) a set of actual and potential resources; (2) the entity consists of several aspects of the social structure, and the entity facilitates the actions of individuals in the structure; (3) horizontal associations; (3) the ability of actors to guarantee benefits; (4) information; (5) norms; (6) values; (7) reciprocity; (8) cooperation; (9) networking. Meanwhile, Coleman (2011) argues that there are six forms of social capital: obligations and expectations, information channels, effective norms and sanctions, power relations, adjusted social organizations, voluntary organizations.

\section{Methodology}

The study was conducted in Benjor village, Tumpang sub-district, Malang Regency, from July to August 2019. The research respondents were 30 local goat farmers. The study used a purposive sampling method that Benjor Village has the potential to increase the local goat population, which is supported by the availability of abundant feed and beef cattle farmers who turn into local goat farmers. Data analysis methods used in research are qualitative and quantitative data analysis. Qualitative with SWOT and quantitative matrix using AHP. IFAS (Internal Strategic Factors Analysis Summary) and EFAS (External Strategic Factors Analysis Summary), followed by AHP (Analytic Hierarchy Process) analysis.

The SWOT matrix will be used to find out a development strategy. The SWOT matrix consists of four types of business development strategies, including:

a) SO (strengths-opportunities) strategy maximizes the strength of the internal environment to take advantage of external environmental opportunities

b) The WO (weaknesses-opportunities) strategy can improve the weaknesses of the internal environment by maximizing opportunities obtained from the external environment

c) Strategy ST (strengths-threats), using strengths owned to minimize the influence of threats from the company's external environment.

d) WT (weaknesses-threats) strategy is a defensive tactic to reduce the influence of weaknesses in the internal environment and avoid threats from the external environment.

The second analysis is AHP. AHP is a appropriate for the conditions of evaluating qualitative attributes. These attributes are mathematically quantitative in a set of pairwise comparisons. The advantages of AHP compared to others are due to the hierarchical structure, as a consequence of the chosen criteria, to the most detailed sub-criteria. Take into account 
validity up to the tolerance limit of the inconsistencies of various criteria and alternatives determined by decision-makers.

\section{Results and Discussion}

\section{Development Strategy of Local Goat}

Benjor Village, Tumpang Subdistrict, Malang Regency is an area that has high potential in developing local goats because of the availability of small ruminant feed. Most farmers are previously raising beef cattle then shifted into local goats because their low financial capital that could not support beef cattle farming. Raising local goats is considered faster and more practical, and marketing is easier. Indicators used for business development strategy include optimization of production, institutions, infrastructure, investment development, logistics systems, and social capital. These indicators are problems found in local goat development.

The results of the SWOT analysis shows that there were many weaknesses in Benjor Village in the local goat development strategy. First, the majority of farmers are not familiar with smartphones to find information about goat farming management. The low education level of the farmers contributes to this condition. The second element of weakness is the frequency of agricultural extension in Benjor Village, rarely done, especially for local goat farmers. Farmers only receive goat grant assistance from Malang Regency Animal Husbandry and Animal Health Service without any technical support. Therefore, farmers' knowledge about providing forage and animal health is limited. The low level of knowledge of farmers on feed processing and the type and sources of feed are the third weakness. The amount of forage and legumes and agricultural waste in large quantities, but farmers do not understand the proper feed composition of protein and energy sources, as well as crude fiber. The fourth weakness is the farmers' low knowledge level on genetics. Genetic cases that arise due to inbreeding. Inbreeding rates are high because the marketing of goats is limited to Benjor Village. The impact of inbreeding is that cattle have genetic disorders/defects. However, genetic defects are assumed by farmers as a myth. The fifth element of weakness is that farmers lack knowledge of the science of reproduction. Reproductive cases that often occur are dystocia and uterine prolapse. Livestock mortality rates in Benjor Village are high because of the condition. The sixth disadvantage is that the price of artificial insemination is expensive ( 80,000 IDR). This has an inbreeding effect. Factors causing inbreeding are farmers prefer to mate their livestock with other livestock in the Benjor Village. The eight weakness is that farmers do not choose artificial insemination because it is expensive, but farmers also do not understand the characteristics of superior males. So that these factors also trigger high inbreeding cases. The tenth weakness is the farmer's lack of knowledge about animal health. The majority of farmers rely on paramedics in the Benjor Village; farmers have not been able to identify the disease and its prevention. The eleventh element is that farmers don't want to form herds. That is due to the weak trust between one farmer to other farmers related to finance. The 12th element of weakness is the condition of infrastructure in Benjor Village. To reach Benjor Village, you must have a private vehicle or rent to send livestock to the livestock market or consumers because public transportation is available. The thirteenth element is the livestock market facilities and abattoirs which are not following the standards so that they are related to the quality of goat meat. The fourteenth element of weakness is the low desire of farmers to cooperate with banks because farmers do not have assets that are used as guarantors. The fifteenth element is the low trust between farmers with others so that they lack empathy.

Local goat development strategies in Benjor Village can thus be categorized in the Multipartite Model. The multiparty model usually involves statutory bodies and private 
companies that join participating farmers. Multipartite out-grower systems can have production determinants. Climate factors, farmer response, management quality, technology quality, financial incentives, government support, influences from external organizations are responsible for credit provision, production, management, processing and marketing. In some cases, farmers are expected to join associations or cooperatives and public institutions are involved as providers of credit and counseling. (Abwino and Riesk, 2006). Opportunities in the local goat development strategy are support from the central government in providing livestock grants to communities in Benjor Village. Goat business development has a high chance of absorbing labor and increasing relations with stakeholders from the public sector, private sector, and the voluntary sector to work together to develop goat agribusiness. Nasution (2002) states that from observing its development from the beginning to the present, the concept of development communication can be seen in a broad and limited sense. In a general sense, development communication includes the role and function of communication (as a reciprocal message exchange activity) among all parties involved in the development effort, especially between the community and the government, from the planning process, then implementation, and evaluation of development. The threat found in the development of local goats is selective investors in selecting farmers. Investors choose farmers who have big capital. Another threat is the role of high levels of marketing in even being able to cause price disparities.

The results of the study show that the position of the local goat development strategy in Benjor Village is in quadrant 3 as follows.

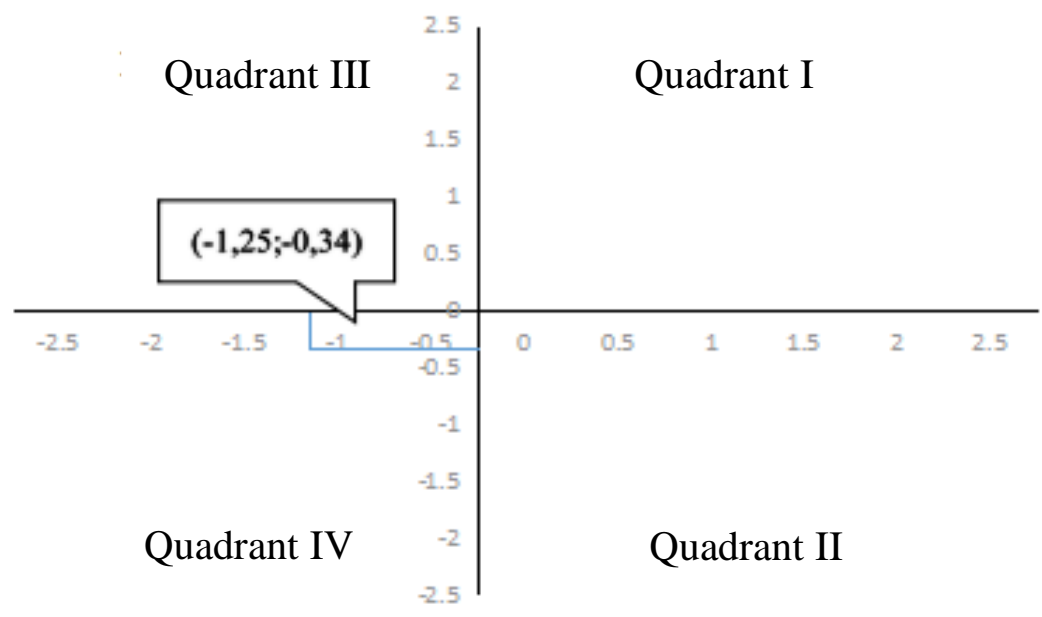

Figure 1. Cartesian Diagram of Local Goat Development Conditions in Benjor Village

Position of local goat development in Benjor Village in quadrant IV. Weakness is higher than strength, and the threat is higher than opportunity. This position is worrying about developing a local goat business. To be able to develop local goats, it must change the strategy that has been done. Four strategies have been made, among others, Building farmers' collaboration with stakeholders (Department of Animal Husbandry, Department of Forestry, Middlemen and other parties) then Build farmer cooperation with external investors with a transparent and fair contract to empower local goat farmers and build big investor confidence in farmers to invest in agribusiness management and participate to strengthen social capital among local goat farmers. Efforts to improve investor credibility, farmers must access external 
information related to technical maintenance to marketing, Build farmers' cooperation with external investors with a transparent and fair contract to empower local goat farmers so that investors who work with farmers are not from the Benjor Village. This situation is also related to the technical aspects of minimizing the occurrence of inbreeding and weakening trust between farmers in Benjor Village.

Based on the strategies made in handling cases in Benjor Village, the next step is to prioritize the strategy to choose which is most needed in Benjor Village through the Analytical Hierarchy Process (AHP) as follows.

Table 2. AHP for Local Goat Development Strategy in Benjor Village

\begin{tabular}{|c|c|c|c|c|c|c|c|c|}
\hline & $\begin{array}{c}\text { Product } \\
\begin{array}{c}\text { Optimalizati } \\
\text { on }\end{array}\end{array}$ & $\begin{array}{c}\text { Institutio } \\
\mathrm{n}\end{array}$ & $\begin{array}{c}\text { Infrastru } \\
\text { cture }\end{array}$ & $\begin{array}{c}\text { Investme } \\
\mathrm{nt}\end{array}$ & $\begin{array}{l}\text { Logistic } \\
\text { System }\end{array}$ & $\begin{array}{l}\text { Social } \\
\text { Capital }\end{array}$ & Criteria & VALUE \\
\hline \begin{tabular}{|l|} 
Building \\
farmer \\
collaboratio \\
n with \\
stakeholders \\
to improve \\
local goat \\
farming \\
\end{tabular} & $\begin{array}{r}0,07683982 \\
7\end{array}$ & $\begin{array}{r}0,490928 \\
189\end{array}$ & $\begin{array}{r}0,244505 \\
495\end{array}$ & $\begin{array}{r}0,124362 \\
245\end{array}$ & $\begin{array}{r}0,1662337 \\
66\end{array}$ & $\begin{array}{r}0,05159 \\
9587\end{array}$ & 0,1253 & 0,191 \\
\hline \begin{tabular}{|l|} 
Improving \\
local goat \\
farming and \\
improving \\
social \\
capital \\
through \\
stakeholder \\
collaboratio \\
n \\
\end{tabular} & $\begin{array}{r}0,15909090 \\
9\end{array}$ & $\begin{array}{r}0,067035 \\
905\end{array}$ & $\begin{array}{r}0,543040 \\
293\end{array}$ & $\begin{array}{r}0,065688 \\
776\end{array}$ & $\begin{array}{r}0,0935064 \\
94\end{array}$ & $\begin{array}{r}0,27481 \\
0802\end{array}$ & 0,2426 & 0,193 \\
\hline \begin{tabular}{|l|} 
Build \\
farmer \\
cooperation \\
with \\
external \\
investors \\
with a clear \\
and fair \\
contract to \\
empower \\
local goat \\
farmers \\
\end{tabular} & $\begin{array}{r}0,26298701 \\
3\end{array}$ & $\mid \begin{array}{r}0,291348 \\
358\end{array}$ & $\begin{array}{r}0,076465 \\
201\end{array}$ & $\begin{array}{r}0,239158 \\
163\end{array}$ & $\begin{array}{r}0,2415584 \\
42\end{array}$ & $\begin{array}{r}0,16860 \\
1651\end{array}$ & 0,0685 & 0,217 \\
\hline $\begin{array}{l}\text { Building big } \\
\text { investor } \\
\text { truts in } \\
\text { farmers to }\end{array}$ & $\begin{array}{r}0,50108225 \\
1\end{array}$ & $\begin{array}{r}0,150687 \\
548\end{array} \mid$ & $\begin{array}{r}0,135989 \\
011\end{array}$ & $\begin{array}{r}0,570790 \\
816\end{array}$ & $\begin{array}{r}0,4987012 \\
99\end{array}$ & $\begin{array}{r}0,50498 \\
796\end{array}$ & 0,1001 & 0,399 \\
\hline
\end{tabular}




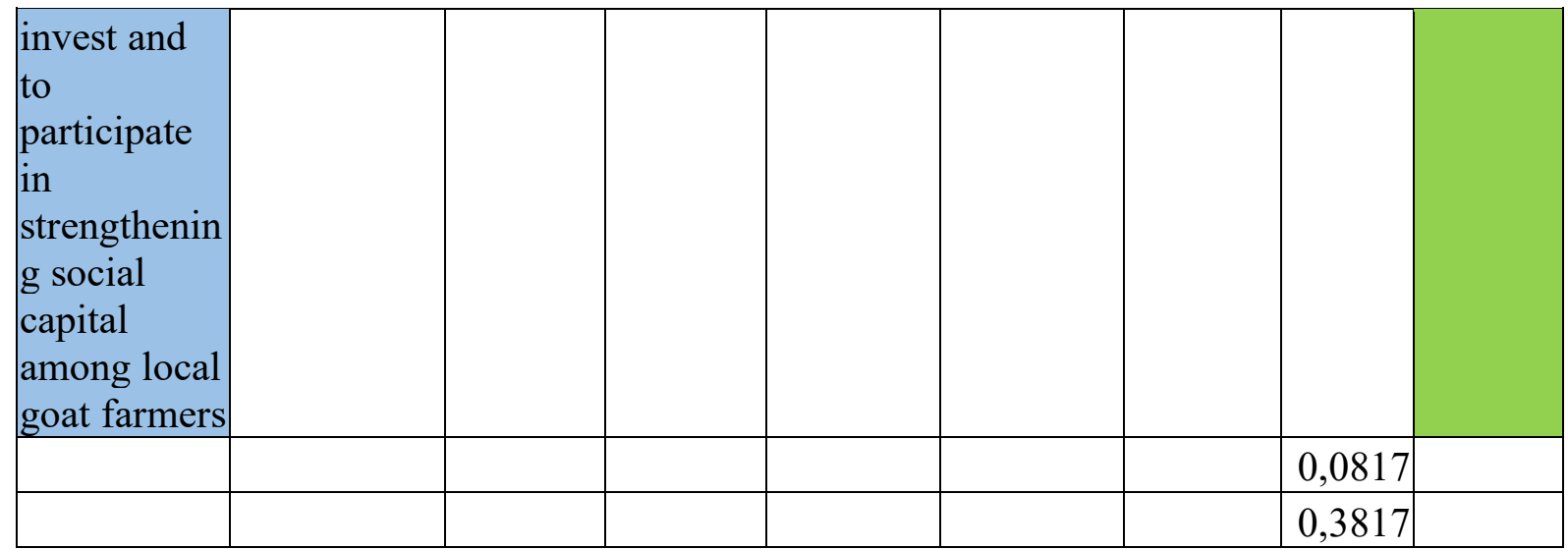

Based on the results of the AHP analysis that two strategies need to be prioritized, primarily related to social capital, namely trust because social capital in terms of the level of trust in Benjor Village is very weak so it needs a strategy to change weaknesses into strength and opportunities, namely by creating big investor trust in farmers to invest in their goat farm, participate in strengthening social capital among local goat farmers and establishing farmers' cooperation with external investors with transparent and fair contracts to empower local goat farmers.

\section{Conclusion}

The position of local goat development in Benjor Village in quadrant IV which means that in that position the weakness is higher than the strength, the threat is higher than the opportunity so that the quadrant IV position is alarming in developing the local goat business, whereas on the other hand Benjor Village has the potential which is prominent in developing local goat businesses. To be able to improve local goats farming, what needs to be done is to change the strategy that has been done before with the four strategies that have been made through the existing conditions. Namely to develop farmers' cooperation with stakeholders (Department of Animal Husbandry, Department of Forestry, Middlemen, and other parties) to improve local goat agribusiness management and social capital through collaboration with stakeholders, especially with various sectors in supporting local goat institutions. It will lead to stimulating farmers' cooperation establishment with external investors with transparent and fair contracts to empower local goat farmers. Proper management and partnership can motivate prominent investors to invest and to participate in strengthening social capital among local goat farmers.

\section{Suggestion}

Further research is the model of local and central government policies on local goat development through the Edward III model.

\section{Acknowledgments}

A greeting is conveyed to the Animal Science Faculty of Universitas Brawijaya, which has assisted in the study of Doctoral research grant year 2019.

\section{References}

[1] Abwino, E.N. dan Rieks, H. 2006. Out-Grower System Through Contract Farming, Zambia. Report. Agro eco. Apopa 
[2] Azizah, S, J.A. Putritamara, and N.Febrianto. 2018. Life Aspects of Small Farmers. UB Press. Indonesia

[3] Banomyong, R. (2007). Logistics Development Study of the North-South Economic Corridor. Manila: Asian Development Bank.

[4] Chen et al. 2005. An empirical investigation of the relationship between intellectual capital and firm's market value and financial performance. Journal of Intellectual Capital, Vol 6, Issue 2.

[5] Cox, L.G. 1970. Farmer's Bargaining Power. Thesis. Kansas State University. Kansa.

[6] Djogo, T., Sunaryo., D. Suharjito, and M. Sirait. 2003. Institutions and Policies in Agroforestry Development. World Asia Southeast Asia Agroforestry Center (ICRAF). Bogor.

[7] Esther, NataliaDwiAstuti, et al. 2013. Application of the Linear Gola Programming Model for Production Planning Optimization. Salatiga: SWCU Science and Mathematics Faculty.

[8] Haridison, Anyualatha. 2013. "Social Capital in Development." JISPAR FISIP University of Palangka Raya No 4.

[9] Kay, R. D., Edward, W.M, and Duffy. P.A. 2004. Farm Management. MacGraw- Hill Inc. New York

[10] Livestock and Animal Health Statistics. 2018. Ministry of Agriculture Directorate General of Animal Husbandry and Health. http://ditjenpkh.pertanian.go.id/userfiles/File/Buku_Statistik_2018 _Final ebook.pdf?time $=1543210844103$.

[11] Mardikanto, T. 1993. Extension of Agricultural Development. Eleven March University Press. Surakarta

[12] Nasution, Z. 2002. Communication Development: Introduction to Theory and Its Application. Revised Edition. Rajawali Press. Jakarta.

[13] Portes, A. 1998. Social Capital: Its Origins and Applications in Modern Sociology. Annual Review of Sociology.

[14] Setiadi, B. 1987. "Study of Etawa Peranakan Goat Characteristics." Thesis. Postgraduate Faculty. Bogor Agricultural Institute. Bogor

[15] Sugiyono 2012. Qualitative Quantitative Research Methods and R\&D. Bandung: Alfabeta.

[16] Suryana, A. 2001. Guidelines for Appropriate Technology Ergonomics for Informal Sector Workers. Ministry of Health of the Republic of Indonesia. Directorate General of Community Health Development. Jakarta 